\title{
PENGARUH MODEL PEMBELAJARAN CORE (CONNECTING, ORGANIZING, REFLECTING, EXTENDING) TERHADAP KEMAMPUAN KONEKSI MATEMATIS SISWA KELAS VIII SMP N 3 RAMBAH
}

\author{
Mardiana ${ }^{1}$, Hera Deswita ${ }^{2}$, Ratri Isharyadi ${ }^{3}$ \\ 1,2,3 Universitas Pasir Pengaraian \\ mardianaaa2018@gmail.com
}

\begin{abstract}
The low ability of students' mathematical connections is caused by the lack of linking learning with previous material and the tendency of students to memorize concepts or formulas. This study aims to see whether there is an effect of the CORE learning model on the mathematical connection ability of grade VIII students of SMPN 3 Rambah. This type of research is a quasi-experimental research with a Two-Group Posttest Only research design. The population in this study were students of class VIII SMPN 3 Rambah. Sampling using simple random sampling technique, class VIII.3 as the experimental class, and class VIII.1 as the control class. The CORE learning model is applied in the practical class, while conventional learning is applied in the control class. The mathematical connection ability data obtained by the test technique. The instrument used was a valid and reliable mathematical connection ability test item. Data analysis was performed for hypothesis testing. Based on the prerequisite test results, it was found that the data were not normally distributed, so that the hypothesis testing was carried out using the Mann Whitney test. The result of the calculation is $3.81>1.96$ with a value of 0.05 , so reject $\mathrm{H}_{0}$ so that it can be concluded that there is an effect of the CORE learning model on the mathematical connection ability of grade VIII students of SMPN 3 Rambah.
\end{abstract}

Keywords: Relating, Experiencing, Applying, Cooperating, and Transferring (REACT), mathematical connection ability.

\begin{abstract}
ABSTRAK Penelitian ini bertujuan untuk mengetahui ada atau tidaknya pengaruh strategi pembelajaran Relating, Experiencing, Applying, Cooperating, and Transferring (REACT) terhadap kemampuan komunikasi matematis siswa kelas VII di MTs Ash-Shohibiyah Bangun Purba. Jenis penelitian ini adalah penelitian Quasi Eksperiment dengan desain the Posttest Only Control Group Design. Populasi pada penelitian ini adalah siswa kelas VII MTs AshShohibiyah Bangun Purba dengan sampel kelas VII.1 dan kelas VII.2. Sampel diperoleh menggunakan teknik random sampling. Kelas eksperimen menggunakan strategi REACT, sedangkan kelas kontrol menggunakan pembelajaran konvensional. Instrumen penelitian ini adalah soal uraian kemampuan komunikasi matematis. Data posttest kemampuan komunikasi matematis yang diperoleh dilakukan analisis data untuk menguji hipotesis. Hasil uji normalitas diperoleh data berdistribusi normal dan hasil uji homogenitas diperoleh data memiliki varian yang tidak homogen. Pengujian hipotesis menggunakan uji †' karena data berdistribusi normal dan tidak homogen, hasil perhitungan diperoleh kesimpulan bahwa ada pengaruh strategi pembelajaran Relating, Experiencing, Applying, Cooperating, and Transferring (REACT) terhadap kemampuan komunikasi matematis siswa kelas VII di MTs AshShohibiyah Bangun Purba.
\end{abstract}

Kata-kata Kunci : Relating, Experiencing, Applying, Cooperating, and Transferring (REACT), kemampuan koneksi matematis. 


\section{PENDAHULUAN}

Matematika sebagai salah satu disiplin ilmu yang diajarkan pada setiap jenjang pendidikan sekolah, diharapkan dapat memberikan sumbangan dalam rangka mengembangkan kemampuan berpikir secara kritis, sistematis, logis, kreatif, dan bekerja sama secara efektif. Sikap dan cara berpikir seperti ini dapat dikembangkan melalui pembelajaran matematika, karena matematika memiliki struktur dan keterkaitan yang kuat dan jelas antar konsepnya, sehingga memungkinkan siapapun yang mempelajarinya terampil dalam berpikir secara rasional dan siap menghadapi permasalahan dalam kehidupan sehari-hari (Setiawan, 2012). National Council of Teachers of Mathematics (2000) merekomendasikan standar- standar kemampuan matematis siswa yakni pemecahan masalah (problem solving), penalaran dan bukti (reasoning and proof), komunikasi (communication), koneksi (connections), dan representasi (representation). Hal ini menunjukkan bahwa kemampuan koneksi matematis perlu dikembangkan dalam pembelajaran matematika sekolah. Koneksi matematis adalah keterkaitan antar topik matematika, keterkaitan antar matematika dengan disiplin ilmu lain, dan keterkaitan matematika dengan dunia nyata atau dalam kehidupan sehari-hari (Latif,dkk,2017). Gagasan tentang pentingnya kemampuan koneksi matematis di Indonesia juga tercantum dalam Badan Standar Nasional Pendidikan (BSNP) mengenai tujuan pembelajaran matematika yaitu menjelaskan keterkaitan antar konsep matematika (BSNP,2006). Kemampuan koneksi matematis merupakan salah satu kemampuan berpikir tingkat tinggi yang sangat penting dan harus dikembangkan karena dalam pembelajaran matematika setiap konsep berkaitan satu sama lain dengan konsep lainnya (Lestari,2014). Kemampuan koneksi matematis antar konteks eksternal di luar matematika dengan matematika saling keterkaitan satu sama lain (Musriliani, 2015). Lasmawati (2011) mengungkapkan bahwa melalui koneksi matematis, wawasan siswa akan semakin terbuka terhadap matematika, yang kemudian akan menimbulkan sikap positif terhadap matematika itu sendiri. Melalui proses koneksi matematis, konsep pemikiran dan wawasan siswa terhadap matematika akan semakin lebih luas, tidak hanya terfokus pada topik yang sedang dipelajari. Dengan melakukan koneksi, konsep-konsep matematika yang telah dipelajari tidak ditinggalkan begitu saja sebagai bagian yang terpisah, tetapi digunakan sebagai pengetahuan dasar untuk memahami konsep yang baru.

Beberapa penelitian menunjukkan bahwa kemampuan koneksi matematis siswa masih tergolong rendah. Penelitian yang dilakukan oleh Warih, dkk (2016) menyimpulkan bahwa kemampuan koneksi matematis siswa MTsN Kota Probolinggo masih rendah. Hal ini terbukti bahwa siswa tidak dapat menerapkan konsep yang telah dipelajari sebelumnya dengan konsep Teorema Pythagoras, sehingga siswa kesulitan dalam menyelesaikan soal. Siswa mengalami kesulitan dalam memahami soal karena siswa masih bingung dan belum mampu memaknai kalimat yang disajikan. Selain itu siswa lupa dengan materi Teorema Pythagoras. Siswa juga kebingungan dalam memilih konsep yang harus digunakan dalam menyelesaikan soal. Selanjutnya, penelitian yang dilakukan oleh Utami menyimpulkan bahwa masih kurangnya kemampuan koneksi matematis siswa terhadap materi kubus, karena hanya terdapat 7 siswa yang mampu mengerjakan soal mengenai indikator menghubungkan antar konsep matematika dan menghubungkan konsep matemattika dengan bidang lain, serta hanya 3 orang yang mampu menjawab pada indikator menghubungkan konsep matematika dengan disiplin ilmu lain, dan pada saat wawancara siswa mengaku tidak paham terhadap tes yang diberikan. 
Berdasarkan hasil observasi peneliti di SMPN 3 Rambah diperoleh informasi bahwa kemampuan koneksi siswa juga masih tergolong rendah. Hal ini disebabkan beberapa faktor. Pertama, saat proses pembelajaran, jarang terdapat penerapan materi pelajaran yang berhubungan dengan materi sebelumnya. Siswa kurang terlatih dalam mengerjakan soal yang berkaitan dengan materi sebelumnya dan kehidupan sehari- hari. Hal ini menyebabkan kemampuan koneksi matematis siswa yang berkaitan dengan konsep sebelumnya dan kehidupan sehari- hari tidak berkembang. Kedua, Dalam mengerjakan latihan-latihan soal, siswa cenderung mengikuti langkah-langkah dari contoh soal yang digunakan oleh gurunya sehingga siswa menjadi tidak mampu menggunakan ide-idenya untuk menemukan langkahlangkah baru atau menghubungkannya dengan materi sebelumnya ataupun dengan dunia nyata. Ketiga, siswa sering lupa (keliru) menggunakan konsep, teorema, rumus dan sebagainya yang akan digunakan dalam menyelesaikan masalah. Hal ini disebabkan karena kecenderungan siswa yang hanya menghapal dan tidak memahami bagaimana konsep, teorema ataupun rumus itu diperoleh. Siswa tidak mampu mengkoneksikan antar konsep matematika dan tidak mampu memahami matematika itu sendiri. Ketidakmampuan siswa tersebut mengakibatkan kemampuan koneksi matematis siswa menjadi tidak tersalurkan.

Menyikapi masalah tersebut, maka perlu dilakukan perbaikan untuk meningkatkan kemampuan koneksi matematis siswa. Salah satu cara untuk meningkatkan koneksi matematis yaitu guru perlu menerapkan model pembelajaran yang dapat memfasilitasi siswa sebagai pusat pembelajaran, menunjang keaktifan, serta kemandirian siswa dalam pembelajaran matematika. Siswa diberi keluasaan dalam berpikir dan melibatkan diri dalam proses pembelajaran. Selain itu, model pembelajaran yang dipilih harus bisa mengkoneksikan antar konsep matematika, baik dengan konsep sebelumnya maupun dengan kehidupan sehari- hari. Model pembelajaran yang bisa diterapkan adalah model pembelajaran CORE (Connecting, Organizing, Reflecting, Extending).

Model CORE adalah suatu model pembelajaran yang menggunakan metode diskusi untuk mempengaruhi perkembangan pengetahuan dengan melibatkan siswa (Pratiwi,2019). Menurut Tamalene (2010) dalam Aryati, dkk (2017) model CORE (Connecting, Organizing, Reflecting, Extending) merupakan model pembelajaran yang berlandaskan pada teori kontruktivisme bahwa siswa harus dapat mengkontruksi pengetahuannya sendiri, melalui interaksi diri dengan lingkungannya. Menurut Ahmad,dkk (2018) pada pembelajaran model CORE siswa akan mengkonstruksi pengetahuannya sendiri dengan cara menghubungkan (connecting) dan mengorganisasikan (organizing) pengetahuan baru dengan pengetahuan lama kemudian memikirkan konsep yang sedang dipelajari (reflecting) serta mahasiswa dapat memperluas pengetahuan mereka selama proses belajar mengajar berlangsung (extending).

Fadillah (2016) mengatakan bahwa ada empat hal yang dibahas dalam pembelajaran dengan model CORE. Pertama, diskusi menentukan koneksi untuk belajar. Kedua, diskusi membantu mengorganisasikan pengetahuan. Ketiga, diskusi yang baik dapat meningkatkan berpikir reflektif. Keempat, diskusi membantu memperluas pengetahuan siswa. Dengan Connecting siswa diajak untuk menghubungkan pengetahuan baru yang akan dipelajari dengan pengetahuannya terdahulu. Organizing membawa siswa untuk dapat mengorganisasikan pengetahuannnya. Kemudian dengan Reflecting, siswa dilatih unutk dapat menjelaskan kembali informasi yang telah merekan dapatkan. Terakhir, yaitu Extending diantaranya dengan kegiatan diskusi, pengetahuan siswa akan diperluas 
(Irawan, 2018).Hal ini, akan menimbulkan motivasi dan pengetahuan yang akan menghasilkan pemaknaan dan pemahaman dalam pembelajaran. Dengan demikian pembelajaran dengan model CORE ini diduga dapat bermanfaat bagi usaha perbaikan proses pembelajaran matematika dalam upaya meningkatkan kemampuan koneksi matematis siswa.

\section{METODE PENELITIAN}

Penelitian ini merupakan penelitian eksperimen semu (Quasi Eksperiment) dengan desain "the posttes only control group design". Desain ini dinyatakan dalam Tabel 1.

Tabel 1. Desain Penelitian The Posttes Only Control Group Design

\begin{tabular}{lll}
\hline \multicolumn{1}{c}{ Kelas } & Perlakuan & Posttest \\
\hline Eksperimen & $\mathrm{X}$ & $\mathrm{O}$ \\
\hline Kontrol & - & $\mathrm{O}$ \\
\hline Sugiyono (2017) & &
\end{tabular}

Keterangan:

$\mathrm{X}=$ Pembelajaran dengan menggunakan pembelajaran strategi REACT

- $\quad=$ Pembelajaran dengan menggunakan pembelajaran konvesional

$\mathrm{O}=$ Tes kemampuan komunikasi matematis.

Penelitian ini telah dilaksanakan di kelas VIII SMPN 3 Rambah tahun ajaran 2019/2020 pada materi pokok sistem persamaan linear dua variabel. Populasi dalam penelitian ini adalah seluruh siswa kelas VIII SMPN 3 Rambah. Teknik penarikan sampel yang digunakan adalah simple random sampling yaitu dengan menggunakan metode undian sehingga diperoleh kelas VIII.3 sebagai kelas eksperimen dan kelas VIII.1 sebagai kelas kontrol. Teknik pengumpulan data dalam penelitian ini dilakukan dengan mengunakan teknik tes, dan instrumen yang digunakan berupa soal uraian yang disusun berdasarkan indikator kemampuan koneksi matematis.

\section{HASIL DAN PEMBAHASAN}

Dari hasil analisis data, secara deskriptif data posttest kemampuan koneksi matematis siswa kelas VIII SMPN 3 Rambah dapat dilihat pada Tabel 2.

Tabel 2. Hasil Deskripsi Data Posttest Kemampuan koneksi Matematis

\begin{tabular}{cccccc}
\hline Kelas & $\mathbf{N}$ & $\bar{X}$ & $\boldsymbol{X}_{\text {maks }}$ & $\boldsymbol{X}_{\text {min }}$ & $\boldsymbol{S}^{\mathbf{2}}$ \\
\hline Eksperimen & 24 & 79,17 & 100 & 33,33 & 239,84 \\
\hline Kontrol & 25 & 62,22 & 100 & 33,33 & 197,54 \\
\hline
\end{tabular}

Berdasarkan Tabel 2 terlihat rata-rata nilai posttest kemampuan koneksi matematis siswa pada kelas eksperimen lebih tinggi dibandingkan dengan rata-rata hasil tes kemampuan koneksi matematis pada kelas kontrol. Nilai maksimum dan minimum kelas eksperimen dan kelas kontrol sama yaitu 100 dan 33. dan varians kelas eksperimen lebih tinggi dari pada kelas kontrol. Varians kelas eksperimen lebih tinggi dari pada kelas kontrol. Hal ini berarti nilai pada kelas eksperimen memiliki keragaman nilai yang lebih bervariasi dari pada kelas kontrol. Adapun perolehan skor siswa 
berdasarkan tiap indikator kemampuan koneksi matematis dapat dilihat pada Tabel 3:

Tabel 3. Hasil Deskripsi Data Kemampuan Koneksi Matematis Setiap Indikator

\begin{tabular}{cllll}
\hline \multirow{2}{*}{ No } & \multicolumn{1}{c}{ Indikator } & \multicolumn{2}{c}{$\overline{\mathrm{X}}$ Skor } & \multicolumn{2}{c}{ Skor } \\
\cline { 3 - 4 } & & Eksp & Kont & Maks \\
\hline 1 & $\begin{array}{l}\text { Menggunakan koneksi antar } \\
\text { topik dalam matematika }\end{array}$ & 2,21 & 1,56 \\
\cline { 1 - 3 } 2 & $\begin{array}{l}\text { Menggunakan matematika } \\
\text { dalam kehidupan sehari- hari }\end{array}$ & 2,50 & 2,36 & 3 \\
\cline { 1 - 2 } 3 & $\begin{array}{l}\text { Menunjukkan representasi } \\
\text { yang ekuivalen dari konsep } \\
\text { yang sama }\end{array}$ & 2,42 & 1,68 \\
\hline
\end{tabular}

Berdasarkan Tabel 3 terlihat bahwa rata-rata skor setiap indikator kemampuan koneksi matematis siswa pada kelas eksperimen lebih tinggi dibandingkan dengan rata-rata skor kemampuan koneksi matematis siswa kelas kontrol, dimana setiap indikator memiliki skor maksimal 3. Hal ini memperlihatkan bahwa pengusaan kemampuan koneksi matematis disetiap indikatornya, kelas eksperimen lebih baik dari pada kelas kontrol.

Sebelum data hasil tes kemampuan koneksi matematis siswa pada kedua kelas sampel dilakukan pengujian hipotesis, terlebih dahulu dilakukan uji prasyarat yaitu uji normalitas dan uji homogenitas. Hasil uji normalitas posttest dapat dilihat pada Tabel 4.

Tabel 4. Hasil Uji Normalitas Data Posttest

\begin{tabular}{llll}
\hline \multicolumn{1}{c}{ Kelas } & Lhitung & Ltabel & \multicolumn{1}{c}{ Kriteria } \\
\hline Eksperimen & 0,16 & 0,19 & Berdistribusi normal \\
\hline Kontrol & 0,24 & 0,19 & $\begin{array}{l}\text { Tidak berdistribusi } \\
\text { normal }\end{array}$ \\
\hline
\end{tabular}

Berdasarkan Tabel 4 terlihat bahwa data kelas eksperimen berdistribusi normal karena Lhitung < Ltabel, sedangkan kelas kontrol Lhitung > Ltabel sehingga data tidak berdistribusi normal. Data memiliki kriteria yang berbeda maka kenormalan diabaikan sehingga kesimpulannya data kelas sampel tidak berdistribusi normal. Hasil pengujian hipotesis mengunakan uji mann whitney diperoleh nilai $z_{\text {hitung }}$ sebesar 3,81 dan nilai $z_{\text {tabel }}$ sebesar 1,96 dengan nilai $\alpha=0,05$, karena $z_{\text {hitung }}>z_{\text {tabel }}$ maka tolak $\mathrm{H}_{0}$. Hal ini berarti ada pengaruh model pembelajaran CORE terhadap kemampuan koneksi matematis siswa kelas VIII SMPN 3 Rambah.

Adapun bentuk peranan-peranan model pembelajaran CORE ini terhadap kemampuan koneksi matematis siswa terlihat pada proses pembelajarannya. Tahap pertama adalah connecting. Pada tahap ini, guru membimbing siswa untuk mengkaitkan materi yang sedang dipelajari dengan materi sebelumnya atau pun dengan kehidupan sehari- hari. Setelah itu, siswa diminta untuk mengamati wacana 
atau masalah yang ada pada LAS, selama proses pembelajaran Guru berkeliling dan memfasilitasi siswa yang bertanya. Tahap kedua yaitu Organizing, pada tahap ini guru membimbing siswa untuk mengorganisasikan pengetahuannya melalui diskusi setelah menemukan keterkaitan antar konsep sehingga mampu memecahkan masalah yang diberikan. Tahap ketiga yaitu Reflecting, pada tahap ini siswa dituntut untuk berfikir reflektif dan bisa menjelaskan kembali informasi yang telah diperoleh. Siswa diminta untuk mempresentasikan hasil diskusi.

Tahap keempat yaitu extending, pada tahap ini guru meminta siswa untuk mengerjakan soal latihan yang ada pada LAS. Soal tersebut bertujuan untuk memperluas wawasan siswa. Sedangkan pada pembelajaran konvensional, guru menyampaikan materi dan memberikan contoh soal. Siswa mendengarkan dan memperhatikan guru menjelaskan materi, menjawab pertanyaan guru dan mencatat materi yang diberikan. Kemudian siswa diberikan latihan berdasarkan contoh yang telah diberikan guru dipapan tulis, siswa selalu mengikuti langkahlangkah yang telah dilejaskan oleh guru dan ketika siswa tidak dapat mengerjakan latihan tersebut, guru langsung menyelesaikan permasalahan tersebut. Pembelajaran biasa (konvensional) disebut sebagai pendekatan langsung. Menurut Suryadi (2015) mendefinisikan pendekatan langsung sebagai suatu pendekatan yang lebih berpusat pada guru. Pembelajaran yang berpusat pada guru tersebut mengakibatkan guru lebih banyak berperan dibandingkan siswa itu sendiri. Selain itu, suasana yang monoton juga dapat mengakibatkan siswa pasif. Siswa tidak terlibat secara optimal dan cenderung menghafal apa yang diberikan guru yang menyebabkan siswa kurang mengeksplor sendiri dalam menyelesaikan soal yang berkaitan dengan koneksi matematis. Akibatnya, hasil kemampuan koneksi matematis siswa kelas kontrol lebih rendah dibanding kelas eksperimen yang diterapkan model pembelajaran CORE.

Berdasarkan keterangan di atas dan hasil analisis uji hipotesis maka dapat disimpulkan bahwa ada pengaruh model pembelajaran CORE terhadap kemampuan koneksi matematis siswa kelas VIII SMPN 3 Rambah tahun ajaran 2019/ 2020.

\section{KESIMPULAN DAN SARAN}

Berdasarkan rumusan masalah, hasil analisis data dan pembahasan hasil penelitian dapat disimpulkan bahwa ada pengaruh model pembelajaran CORE terhadap kemampuan koneksi matematis siswa kelas VIII SMPN 3 Rambah tahun ajaran 2019/2020, dan nilai rata-rata kemampuan koneksi matematis siswa yang menggunakan model pembelajaran CORE lebih tinggi daripada nilai rata-rata kemampuan koneksi matematis siswa yang menggunakan pembelajaran konvensional. Berdasarkan hasil penelitian ini, peneliti memberikan saran yang berhubungan dengan model pembelajaran CORE yaitu sebagai berikut:

1. Guru matematika dapat menerapkan model pembelajaran CORE sebagai alternatif diantara banyak pilihan model pembelajaran matematika yang mampu meningkatkan kemampuan koneksi matematis siswa. 
2. Peneliti lain dapat menerapkan model pembelajaran CORE dikombinasikan dengan variabel-variabel yang lain dan untuk meningkatkan kemampuan matematis yang lain.

3. Sekolah maupun guru harus mengetahui pentingnya kemampuan koneksi matematis siswa, karena ketika kemampuan koneksi matematis siswa baik akan berpengaruh terhadap hasil belajar siswa.

\section{DAFTAR PUSTAKA}

Ahmad, B., Deswita, R., Ningsih, F., \& Syafriadi, S. (2018). Pengaruh Model Pembelajaran CORE dengan Pendekatan Scientific Terhadap Kemampuan Pemecahan Masalah Matematis dan Mathematical Habits of Mind Mahasiswa Matematika. Tarbawi: Jurnal IImu Pendidikan, 13(2), 33-42.

Aryati, T. A., SANTIKA, T., \& KARTIKA, H. (2017). Pengaruh Model Pembelajaran Core (Connecting, Organizing, Reflecting, Extending) terhadap Kemampuan Koneksi Matematis Siswa SMP Kelas VIII. In Prosiding Seminar Nasional Matematika dan Pendidikan Matematika (SESIOMADIKA) (pp. 517-525).

BSNP. 2006. Standar Isi Untuk Satuan Pendidikan Dasar dan Menengah. Jakarta: BSNP.

Fadillah, A. (2016). Pembelajaran Matematika Dengan Model CORE Melalui Pendekatan Keterampilan Metakognitif Terhadap Kemampuan Penalaran Matematis Siswa Smp. Prima: Jurnal Pendidikan Matematika, 5(2), 15-24.

Irawan, B. P. (2018). Pengaruh Model Pembelajaran CORE (Connecting, Organizing, Reflecting, Extending) Terhadap Kemampuan Pemahaman Konsep dan Kemampuan Penalaran Matematika Siswa Sekolah Menengah Kejuruan. Journal of Mathematics Science and Education, 1 (1), 38-54.

Latif, S. (2017). Mathematical Connection Ability In Solving Mathematics Problem Based On Initial Abilities Of Students At SMPN 10 Bulukumba. Daya Matematis: Jurnal Inovasi Pendidikan Matematika, 4 (2), 207-217.

Lasmanawati. (2011). Pengaruh Pembelajaran Menggunakan Pendekatan Proses Berpikir Reflektif terhadap Peningkatan Kemampuan Koneksi dan Berpikir Kritis Matematis Siswa. Tesis SPS UPI. Bandung: tidak diterbitkan.

Lestari, K. E. (2014). Implementasi Brain-Based Learning untuk meningkatkan kemampuan koneksi dan kemampuan berpikir kritis serta motivasi belajar siswa SMP. Judika (Jurnal pendidikan UNSIKA), 2(1).

Musriliani, C., Marwan, M., \& Ansari, B. I. (2015). Pengaruh Pembelajaran Contextual Teaching Learning (CTL) terhadap Kemampuan Koneksi Matematis Siswa SMP Ditinjau dari Gender. Jurnal Didaktik Matematika, 2 (2).

NCTM. (2000). Principles and Standards for School Mathematics. USA : The National Council of Teachers of Mathematics, Inc.

Pratiwi, S. I., Lusiana, L., \& Fuadiah, N. F. (2019). Peningkatan Kemampuan Pemahaman Konsep Matematis Siswa SMPN 30 Palembang Melalui Pembelajaran CORE. Jurnal Pendidikan Matematika Raflesia, 4(2), 15-28.

Setiawan. (2012). Meningkatkan Kemampuan Koneksi dan Pemecahan Masalah Matematik Siswa melalui Pembelajaran Kooperatif Model Cooperative Integrated Reading and Composition (CIRC). Tesis. SPS UPI: Tidak diterbitkan. 
Suryadi, D. (2015). Penggunaan Pendekatan Pembelajaran Tidak Langsung Serta Pendekatan Gabungan Langsung dan Tidak Langsung dalam Rangka Meningkatkan Kemampuan Berfikir Matematik Tingkat Tinggi Siswa SLTP. Desertasi UPI. Bandung: tidak diterbitkan.

Utami, V., \& Effendi, K. N. S. (2019). ANALISIS KEMAMPUAN KONEKSI MATEMATIS SISWA SMP PADA MATERI KUBUS. Prosiding Sesiomadika, 2(1).

Warih, S., Dwi, P., Parta, I. N., \& Rahardjo, S. (2016). Analisis kemampuan koneksi matematis siswa kelas VIII pada materi teorema Pythagoras. Prosiding. Konferensi Nasional Penelitian Matematika dan Pembelajarannya (KNPMP I) UMS. 